\title{
Water-Level Changes in the High Plains Aquifer, Predevelopment to 2001, 1999 to 2000, and 2000 to 2001
}

\section{-By V.L. McGuire}

The High Plains aquifer underlies one of the major agricultural regions in the world, including parts of eight states-Colorado, Kansas, Nebraska, New Mexico, Oklahoma, South Dakota, Texas, and Wyoming. In the area overlying the High Plains aquifer, the total number of acres irrigated with ground water increased rapidly after 1940 and was 2.1 million acres in 1949, 13.7 million acres in 1980, and 13.9 million acres in 1997 (Heimes and Luckey, 1982; Thelin and Heimes, 1987; U.S. Department of Agriculture, 1999). Water-level declines started to occur in the High Plains aquifer soon after the beginning of extensive ground-water irrigation. The water-level declines in the High Plains aquifer occur because of an imbalance between discharge, the largest component of which is ground-water withdrawals for irrigation, and recharge, which is primarily from precipitation. By 1980, water levels in the High Plains aquifer in parts of Texas, Oklahoma, and southwestern Kansas had declined more than 100 feet (Luckey and others, 1981).Water-level declines may result in additional cost for ground-water withdrawals because of increased pumping lift and decreased well yields. Water-level declines also can affect ground-water availability, streamflow, and health of riparian areas. In response to the water-level declines, the U.S. Geological Survey, in cooperation with numerous Federal, State, and local waterresource agencies, began a monitoring program in 1988 to assess annual water-level change in the aquifer using measurements from more than 7,000 wells. The purpose of this report is to present water-level changes in the High Plains aquifer from the time prior to significant ground-water irrigation development (termed predevelopment in this report) to 2001, 1999 to 2000, and 2000 to 2001. The water-level measurements used in this report were collected in winter or early spring when irrigation wells generally were not pumping.

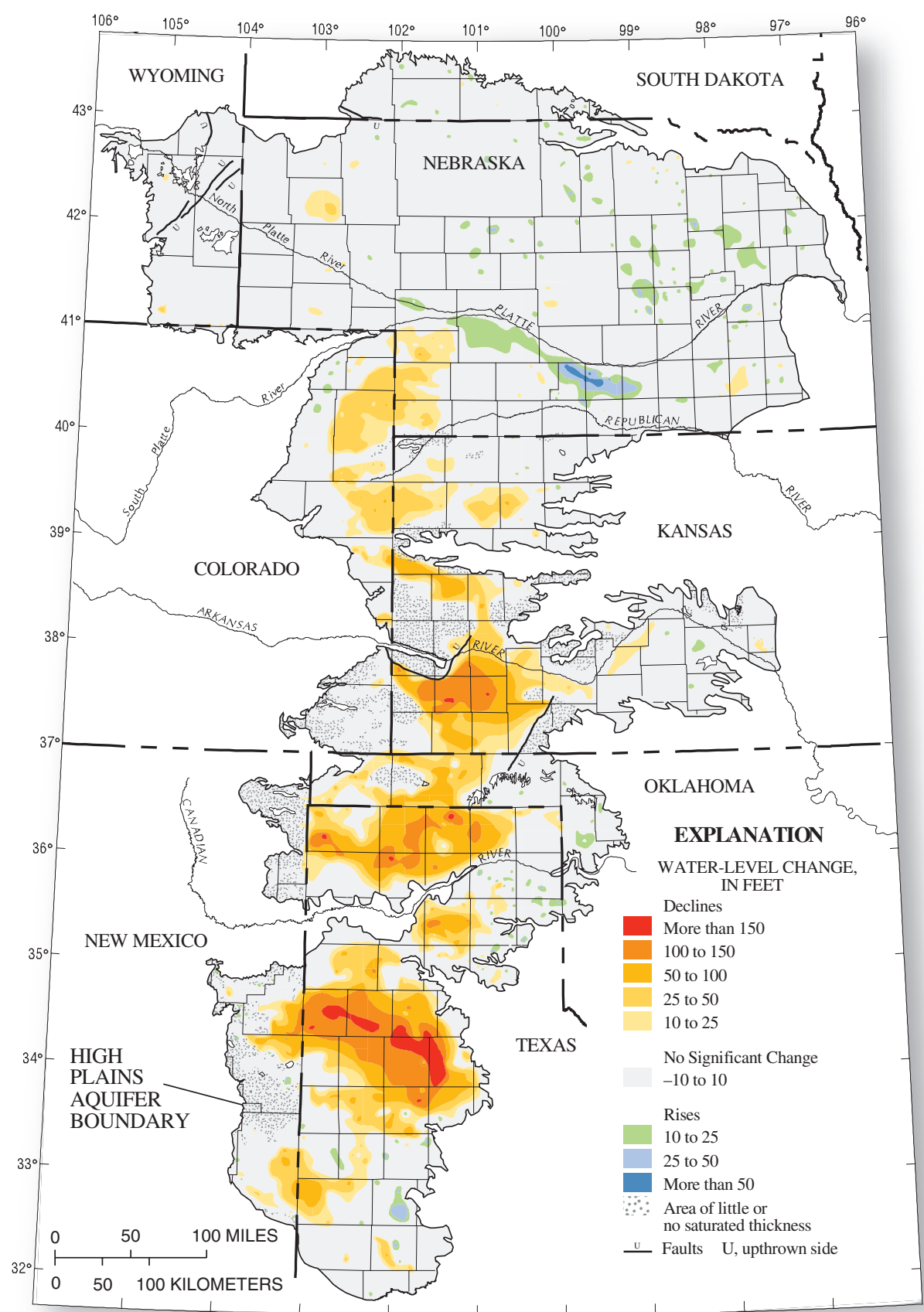

Base from U.S. Geological Survey digital data, 1:2,000,000

Albers Equal-Area projection

Standard parallels $29^{\circ} 30^{\prime} \mathrm{N}$ and $45^{\circ} 30^{\prime} \mathrm{N}$, central meridian $101^{\circ} \mathrm{N}$

Figure 1. Water-level changes in the High Plains aquifer, predevelopment to 2001 (Modified from Luckey and others, 1981; McGuire and Fischer, 1999). 
The water-level change maps in this report were prepared using two methods. The map of water-level changes, predevelopment to 2001 (fig. 1) was contoured manually using the predevelopment to 2001 water-levelchange values for each well. The water-level change maps, 1999 to 2000 and 2000 to 2001 (fig. $2 A$ and fig. $2 B$ ) were generated using Thiessen-polygons (Thiessen, 1911). A Thiessen polygon was created for each well; the size of each polygon depends on the proximity of neighboring wells.

\section{WATER-LEVEL CHANGES, PREDEVELOPMENT TO 2001}

The map of water-level changes in the High Plains aquifer from predevelopment to 2001 (fig. 1) is based on water levels from 4,071 wells (table 1). The area-weighted average water-level change was a decline of 11.1 feet, and the water removed from the aquifer through 2001 is estimated to be about 200 million acre-feet. The greatest water-level changes occurred in southwestern Kansas and in the southwestern part of the Texas Panhandle (fig. 1). In most of the southwestern part of the Texas Panhandle, more than 50 percent of the predevelopment saturated thickness has been dewatered (McGuire and Fischer, 1999).

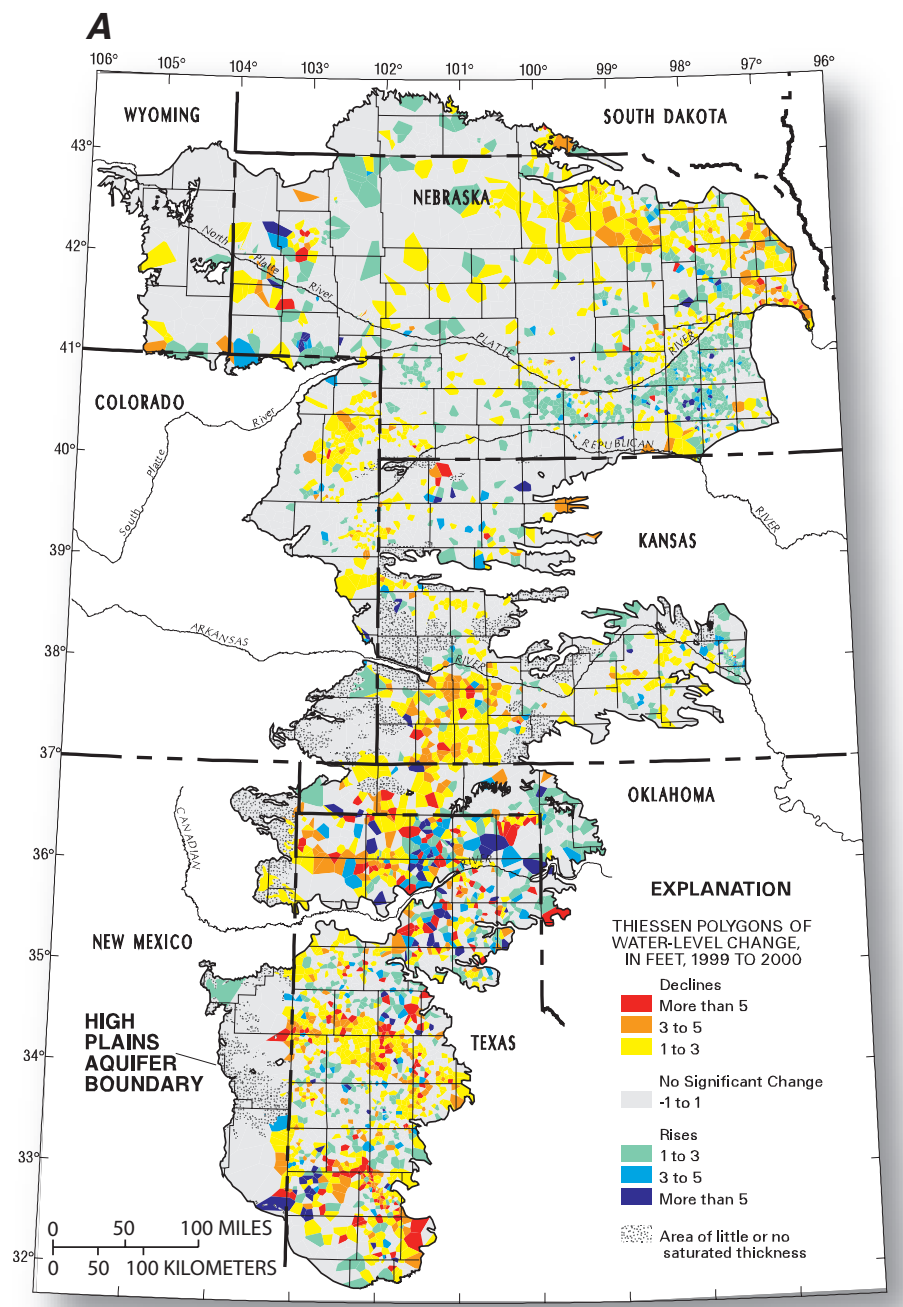

\section{WATER-LEVEL CHANGES, 1999 TO 2000 AND 2000 TO 2001}

Ninety-nine percent of all water-level changes from 1999 to 2000 were from a rise of 7.4 feet to a decline of 8.3 feet. The average area-weighted water-level change in the High Plains aquifer was a decline of 0.23 foot from 1999 to 2000 based on measurements from 7,403 wells (table 1). The largest areas of water-level decline are in northeast Nebraska, northeast Colorado, southwest Kansas, the Oklahoma Panhandle, and most of the aquifer area in Texas (fig. 2A).

Ninety-nine percent of all water-level changes from 2000 to 2001 were from a rise of 7.4 feet to a decline of 8.7 feet. The average area-weighted water-level change in the High Plains aquifer was a decline of 0.62 foot from 2000 to 2001 based on measurements from 7,650 wells (table 1). Water-level declines occurred over most of the aquifer area except in part of Texas, primarily north of the Canadian River where water-level rises occurred (fig. $2 B$ ).

The cumulative loss of water in storage in the aquifer from 1987 to 2002 is about 56 million acre-feet (fig. 3), which represents about 29 percent of the cumulative loss since predevelopment.

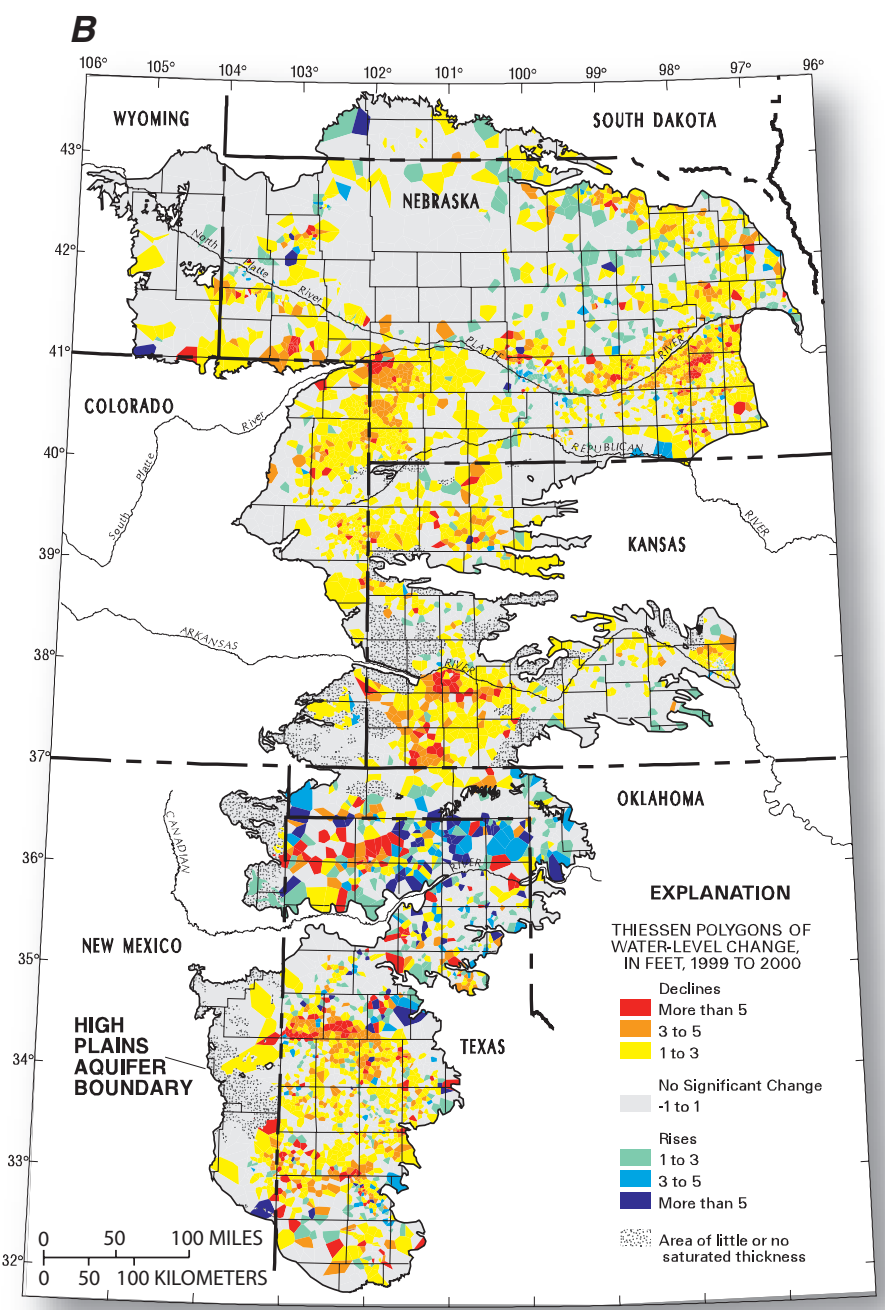

Figure 2. Generalized water-level changes in the High Plains aquifer, (A) 1999 to 2000 and (B) 2000 to 2001. 
Table 1. Number of wells measured and used in this report for predevelopment, 1999, 2000, and 2001 and number of wells used for the water-level comparison periods-predevelopment to 2001, 1999 to 2000 , and 2000 to 2001.

\begin{tabular}{|c|c|c|c|c|c|c|c|}
\hline \multirow{2}{*}{ State } & \multicolumn{4}{|c|}{ Wells measured and used in this report } & \multicolumn{3}{|c|}{$\begin{array}{l}\text { Wells used in water-level } \\
\text { comparison periods }\end{array}$} \\
\hline & Predevelopment & 1999 & 2000 & 2001 & $\begin{array}{l}\text { Predevelopment } \\
\text { to } 2001\end{array}$ & $\begin{array}{l}1999 \text { to } \\
2000\end{array}$ & $\begin{array}{l}2000 \text { to } \\
2001\end{array}$ \\
\hline Colorado & 614 & 570 & 548 & 557 & 404 & 531 & 527 \\
\hline Kansas & 4,169 & 1,266 & 1,214 & 1,366 & 634 & 1,163 & 1,153 \\
\hline Nebraska & 6,681 & 3,604 & 3,699 & 3,849 & 1,710 & 3,275 & 3,537 \\
\hline New Mexico & 3,197 & 24 & 167 & $525^{\mathrm{a}}$ & $319^{\mathrm{a}}$ & 18 & 89 \\
\hline Oklahoma & 1,270 & 242 & 214 & 242 & 163 & 175 & 167 \\
\hline South Dakota & 72 & 112 & 160 & 113 & 72 & 93 & 94 \\
\hline Texas & 4,823 & 2,515 & 2,541 & $2,525^{\mathrm{b}}$ & $750^{\mathrm{b}}$ & 2,098 & $2,028^{\mathrm{b}}$ \\
\hline Wyoming & 26 & 53 & 59 & 60 & 19 & 50 & 55 \\
\hline High Plains (Total) & 20,852 & 8,386 & 8,602 & 9,237 & 4,071 & 7,403 & 7,650 \\
\hline
\end{tabular}

崩
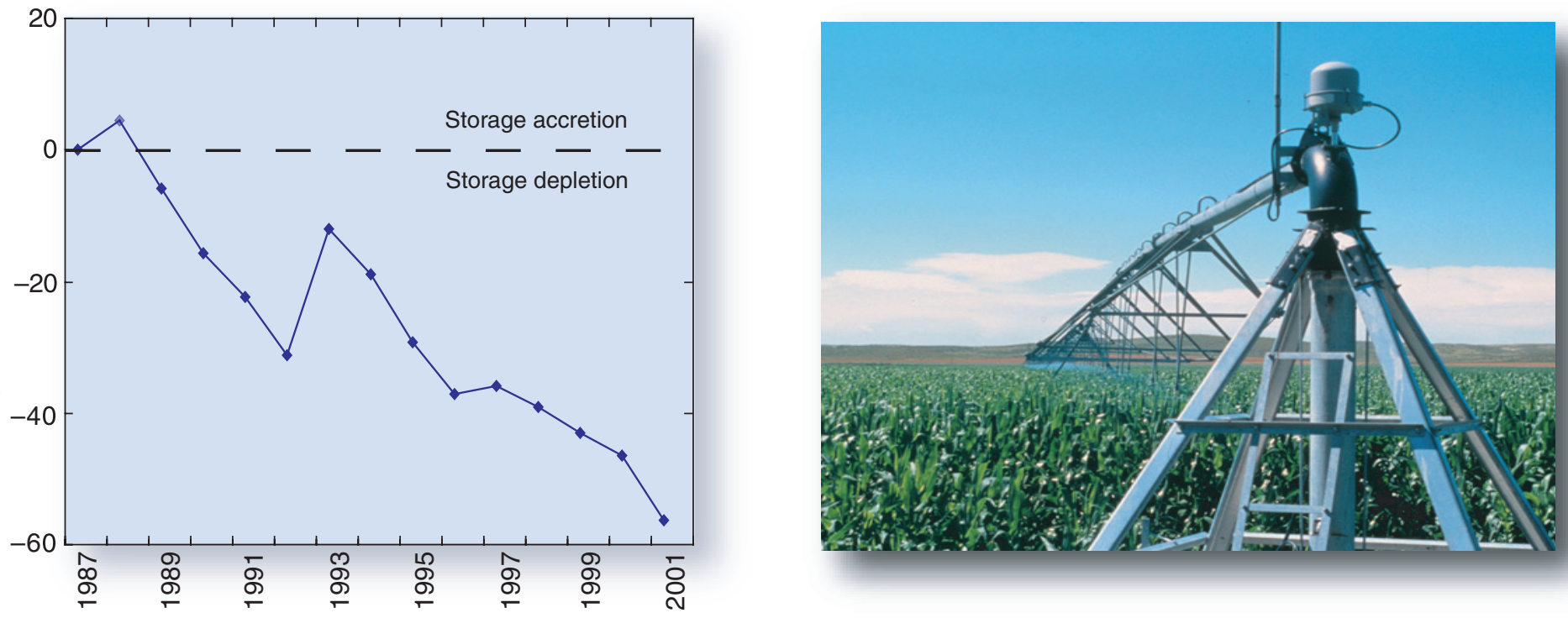

Figure 3. Cumulative changes in ground-water storage in the High Plains aquifer since 1987 (modified from U.S. Geological Survey, 2002).
A center-pivot irrigation system with drop tubes, in Dundy County, Nebraska (Photograph courtesy of M.K. Landon, U.S. Geological Survey.) 


\section{REFERENCES}

Heimes, F.J., and Luckey, R.R., 1982, Method for estimating irrigation requirements from ground water in the High Plains in parts of Colorado, Kansas, Nebraska, New Mexico, Oklahoma, South Dakota, Texas, and Wyoming: U.S. Geological Survey Water-Resources Investigations Report 82-40, 64 p.

Luckey, R.R., Gutentag, E.D., and Weeks, J.B., 1981,

Water-level and saturated-thickness changes, predevelopment to 1980, in the High Plains aquifer in parts of Colorado, Kansas, Nebraska, New Mexico, Oklahoma, South Dakota, Texas, and Wyoming: U.S. Geological Survey Hydrologic Investigations Atlas HA-652, 2 sheets, scale 1:2,500,000.

McGuire, V.L. and Fischer, B.C, 1999, Water-level changes, 1980 to 1997 , and saturated thickness, 1996-97, in the High Plains Aquifer: U.S.

Geological Survey Fact Sheet, FS-124-99, 4 p.

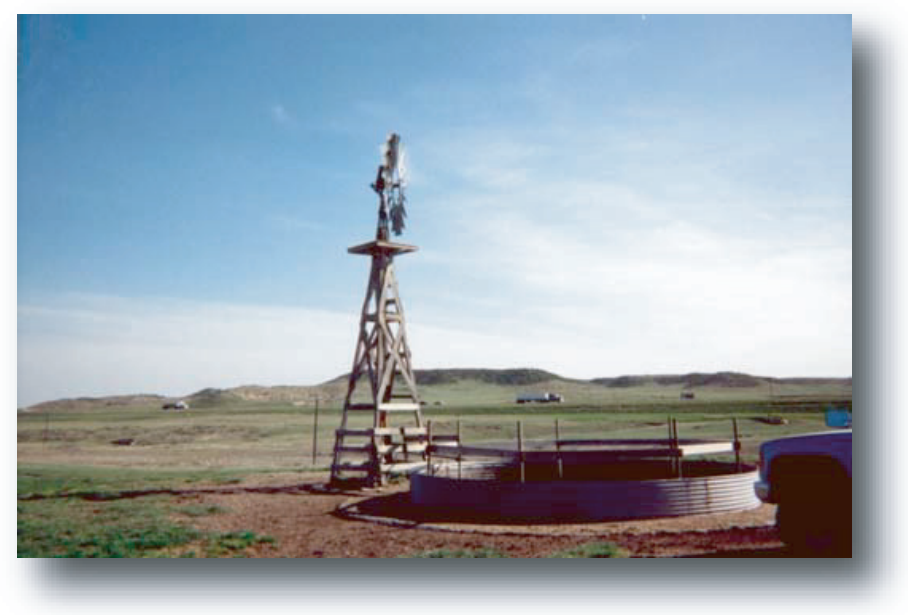

Windmill-powered well and livestock-watering tank, Platte County, Wyoming (Photograph courtesy of J.P. Mason, U.S. Geological Survey.)
Thiessen, A.H., 1911, Precipitation averages for large areas: Monthly Weather Review, v. 39, p. 10821084.

Thelin, G.P., and Heimes, F.J., 1987, Mapping irrigated cropland from Landsat data for determination of water use from the High Plains aquifer in parts of Colorado, Kansas, Nebraska, New Mexico, Oklahoma, South Dakota, Texas, and Wyoming: U.S. Geological Survey Professional Paper 1400-C, 38 p.

U.S. Department of Agriculture, 1999, 1997 Census of Agriculture Geographic area series: National Agricultural Statistics Service CD-ROM AC97-CDVOL1-1B.

U.S. Geological Survey, 2002, Concepts for national assessment of water availability and use: U.S. Geological Survey Circular 1223, 34 p.

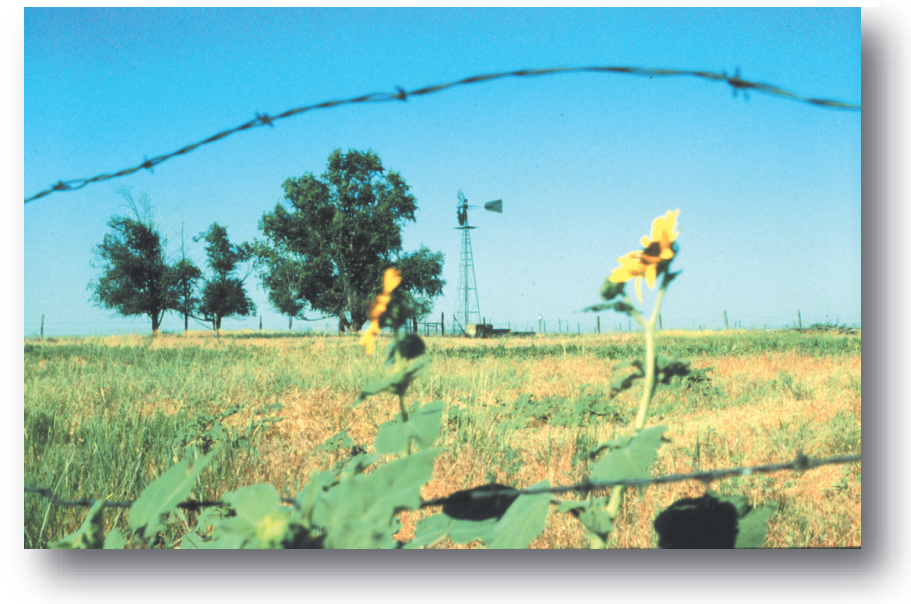

Rangeland in Kit Carson County, Colorado (Photograph courtesy of R.R. Luckey, U.S. Geological Survey.)
For additional information contact:

U.S. Geological Survey, Federal Bldg., Room 406, 100 Centennial Mall North Lincoln, NE 68508 (402) 437-5082 USGS Nebraska District home page: http://ne.water.usgs.gov 